\title{
Transformational and Transactional Leadership Styles in Enhancing Nurse Educator's Job Satisfaction: An Integrative Analysis of Conventional and Islamic Approaches.
}

\author{
Soo-Foon Moey ${ }^{1}$, Abdurezak Abdulahi Hashi ${ }^{2}$ \\ ${ }^{1}$ Department of Diagnostic Imaging, Kulliyah Allied Health Sciences, IIUM \\ ${ }^{2}$ Department of Biotechnology, Kulliyah of Science, IIUM
}

\begin{abstract}
As nursing education gets more complex, leadership styles employed in these nursing training institutions played a crucial role in achieving nurse educators' job satisfaction. As such, this study intends to elicit attributes and practices of nursing academic leaders' transformational and transactional leadership styles in enhancing the job satisfaction of nurse educators. The qualitative method used for the study was based on the phenomenological approach to gather an in-depth understanding of human behaviour through interview, documents and observations. Purposive sampling was undertaken in selecting nine nurse educators from three nursing colleges from Johor and Melaka. Data from the interview were summarized in answering nurse educators' job satisfaction and perceived leadership styles and practices of nursing academic leaders. The responses from the verbatim transcriptions were analysed using the software Atlas $\mathrm{Ti}$. The strong relationship between nursing academic leadership styles and nurse educators' job satisfaction suggested that the academic nursing transformational leadership style played a prominent role on subordinates' job satisfaction and that nursing academic leaders' transformational leadership practices and attributes had the ability to encourage subordinates to achieve more than what they planned. Transactional leadership practised by the nursing academic leaders indicated a weak link to subordinates' job satisfaction as the leaders' emphasis on payoffs for performance and corrective actions were not as acceptable to that of transformational leadership attributes practised by the leaders. The study uncovered effective leadership was enacted via engaging leadership where the leader enabled the development of an organization modelled by a culture of integrity, transparency, accessibility and genuine valuing of others and that their contributions were concerned for the development and well-being of others. In fact, moral attributes like integrity, trustworthiness and commitment to work as well as decision making styles of leaders such as being consultative leader are among the basic Islamic teachings on establishing worthy social order.
\end{abstract}

KEYWORDS: Transformational leadership, job satisfaction, nurse educators and leaders, approaches.

\section{INTRODUCTION}

Although nursing administrators comprise only a small portion of the current nursing population, they are a critical group as the impact of work environment is largely dependent on them. Research had shown commensurable effect that nursing managers had on the morale and job satisfaction of nurses. ${ }^{1}$ This is further reaffirmed by Loke-Foong ${ }^{2}$ who indicated that nurse managers' behavioural attributes did indeed impact subordinates' job satisfaction as well as commitment, including that of productivity. As such nursing managers' leadership skills play a key role towards job

Corresponding author:

Soo-Foon Moey

Department of Diagnostic Imaging,

Kulliyah Allied Health Sciences,

International Islamic University Malaysia,

Jalan Sultan Ahmad shah,

25200 Kuantan,

Pahang, Malaysia

Email: moeysf@iium.edu.my satisfaction and retention and as such, can mitigate the nursing shortages. ${ }^{3}$ Thus, the ability to retain nurse educators is one of the most important aspects of a nursing administrator's responsibility. ${ }^{4}$ Reported that the key to productivity, motivation and retention of subordinates lies in the hands of their leaders. He further reiterated that nursing leadership is demonstrated by close relationships with their subordinates.

Turnover is particularly problematic for nurse educators because of the high cost and time required to attain the experience and expertise required of them to function effectively. ${ }^{5,6}$ Thus, the ability to retain nurse educators is one of the most important aspects of a nursing administrator's responsibility. It is therefore important to continue to investigate how, why and what perceived leadership styles that can have an impact on nurse educators' job satisfaction and thus help in the retention. Furthermore, the positive effects of transformational and transactional leadership on 
subordinates are relatively well researched in the nursing faculty in the western countries. However, to the best of the researcher's knowledge, no study has been conducted in the nursing colleges or programmes under the Ministry of Health, Malaysia $(\mathrm{MOH})$ to examine how transformational and transactional leadership particularly in relation to nursing academic leadership behaviours with subordinates overall job satisfaction.

Research conducted outside the healthcare arena suggested that leadership attributes relatedness in improving followers' job satisfaction included that of edifying leader-follower relationship based on mutual trust and respect, being visible and accessible, reliable, virtuous and living one's embraced values, training, mentoring staff, role modelling and engaging in communication that reflects understanding, mutual respect and interest. ${ }^{7,8}$ In particular, researchers have hypothesized that nursing administrators require effective leadership styles, high social and interpersonal abilities together with political astuteness to remain effective in an ever-increasing competitive environments so as to be able to propel the organization during times of potential crisis and change. ${ }^{3}$ It is believed that by continuously gauging and improving leaders' effectiveness and work environment, it can result in the increase of job satisfaction. ${ }^{9}$

Bass $^{10}$ indicated that transactional leadership emphasizes on role identification, expectations, performance factors and managing to reap anticipated outcomes. Transformational leadership on the other hand, moves the entire attention of performance and anticipations of work that exceeds expectations of quality and speed of feat as well. The transformational leader works with subordinates in stimulating their thinking and arousing their feat to perform beyond anticipations. ${ }^{11}$ In short, the transformational leader excels from a simple to a multifaceted exchange process, inspiring subordinates to the higher hierarchal needs. ${ }^{12}$ Bass and Avolio ${ }^{13}$ also stressed that this century requires leadership with transformational attributes; supple, developmentally adapted, "open-minded" and capitalizing on these attributes has the capability to face up to a learned workforce.

A deeply satisfying organizational culture could solidify if leaders involve subordinates in the development of shared work values. The relationship of leadership styles and subordinates' job satisfaction is supported by research ${ }^{1}$ and improved leadership styles can improve subordinates' perceptions of leadership support, thus aiding in enhancing job satisfaction of the subordinates. ${ }^{28}$ Moral quality of leaders and their relation to their communities are also among the subjects addressed by major religious traditions including Islam. The Islamic perspective of work ethics is found in the Qur'anic terms like ajir (employee), ra'i (shepherd) and ulul amri (decision makers) which collectively connote those who hold public offices, or in charge of given employment and given duties including heads of states, directors of corporate business companies, private firms, chancellors of educational institutions, as well as the welfare organizations. With regards to the leadership characteristics of public administrators, the early Muslim scholars like; Abu Yusuf (731-798 A.D), Ibn al-Muqafa (724-789A.D), and al-Mawardi (d.1058 C.E) emphasized the personal and judicial aspects of the public administrators under the topics; "al-wali al-adil", "al-sultan al-"Adil" or the "khalifah" which are all equivalent to "just leader or administrator". Among classical Muslim writings on this subject include al-Adab al-Kabir and al-Adab as-Saghir, by Ibn al-Muqafa (d. 789 CE), al-Mizan alAmal, by al-Ghazali (d. 1111 CE), al-Ahkam alSultaniyah wal Wilayah al-Diniyyah, by Almawardi (d. $1058 \mathrm{CE}$ ), Besides their enormous effort which was heavily invested in the descriptions of the "sultan "adil", these scholars made a considerable effort on explaining the managerial roles and leadership styles of leader through and within the Islamic perspective. Contemporary Muslim works on this subject are also available including that of Shaukat Ali and Qardhawi, which offered valuable discussions on the subject.

Thus, this study intends to determine the effects of transformational and transactional leadership styles on nurse educators' overall job satisfaction with the emphasis of answering the following research questions: 1. What factors have influenced nurse educators' job satisfaction? 2. How do nurse educators perceive the leadership styles of their nurse administrators? 3. What specific leadership practices if any have encouraged nurse educators' job satisfaction?

\section{MATERIALS AND METHODS}

This study employed a qualitative method together with documents and observations. Purposive sampling that included maximum variation sampling and critical case sampling in selecting nine nurse educators from three nursing colleges from Johor and Melaka were selected for the study. The methodological naturalism is the phenomenological assumption that provides the framework with which to conduct this study. The naturalistic study used in the qualitative process was to emphasize a phenomenological view to find meaning from events as they occur ${ }^{14}$ so as to enable greater understanding regarding nurse educators' perceptions, opinion and feelings as they relate to their leadership styles and their own level of job satisfaction. The charted responses were then analyzed using qualitative statistical software; Atlas $\mathrm{Ti}$ to identify common themes that occurred.

Purposive sampling was used in qualitative method as opposed to that of random sampling in the case of quantitative method to include purposely selected samples to represent a wide range of things that could be observed by the inquirer. Contact with the college directors from three nursing colleges were by letter as well as by phone 
to obtain their approval in permitting their college participation in the study. As qualitative study aims to obtain rather implicit deep information, their sampling size is rather small. ${ }^{15}$ As such, three nurse educators from each college were selected as participants in the study. Three colleges in close proximity to the researcher were selected for the study. College A and B are nursing colleges conducting diploma program whereas College C conducts certificate program in Community Nursing. All the administrative leaders under study have at least 15 years of experience and had served the colleges no less than two years. The name of the colleges and participants were omitted to preserve confidentiality and anonymity. Informed consent and the right to withdraw from the interview were told to the participants before the start of the interview. The interview was conducted using a structured interview guide. The initial data was in the form of verbatim transcriptions of the nine interviews. Each interview was then summarized into a narrative form that included direct quotations according to the questions that were answered: data relating to nurse educators' job satisfaction and perceived leadership styles and practices of nursing academic leaders.

Trustworthiness and rigor of the data were ascertained using the parallel criteria. ${ }^{16}$ Credibility of the data was achieved by persistent observation and engagement with nurse educators to elicit attributes and practices of leaders that contributed to their job satisfaction as well as other factors leading to their job satisfaction. Further, the researcher develops a reflexive journal in which regular entries are made during the research process pertaining to methodological decisions and the reasons for them, the logistics of the study and a reflection of what is happening in terms of her own values and interests. Additionally, transcriptions of the data were checked by the participants in ensuring internal validity. Data dependability was achieved by ensuring that the findings derived were explicit, repeatable and consistent across time by using the same semistructured interview guide for all participants and using the same interviewer. Data saturation was used to ensure data adequacy that data were gathered to the point of redundancy. The use of multiple data sources; participant observation, field notes, participant checks, site documents and journals further augment adequacy in terms of data variability and interpretive status of the evidence. Adequacy in interpretation involved immersion in the data during data collection and transcription of interviews by repetition of transcription readings, tape listening, review of field notes and other data.

\section{RESULTS}

Participants' profile for the qualitative study is shown in Table I. All nine nurse educators' age ranges between 42 years to 56 years and six of them are married and the rest have never married. Three of them have at least two years in teaching, three with at least five years in teaching and another three, more than ten years in teaching. All

Table I: Demographic Factors of the Participants Interviewed

\begin{tabular}{cccccc}
\hline Nursing College/ & Participants & Location & Age & Marital Status & Job Tenure \\
& 1 & (Melaka) & 45 & Married & 2 years \\
A & 2 & & 51 & Married & 9 years \\
& 3 & & 55 & Never Married & 14 years \\
& 4 & (Johor) & 56 & Married & 16 years \\
B & 5 & & 44 & Married & 2 years \\
& 6 & & 47 & Never Married & 6 years \\
& 7 & (Johor) & 51 & Married & 11 years \\
C & 8 & & 42 & Never Married & 3 years \\
& 9 & & & Married & 6 years \\
\hline
\end{tabular}

three of the participants from the same college under study teach different content areas.

Each interview was then summarized into a narrative form that included direct quotations and paraphrases from the participants' responses. Key words or paraphrases were then coded into data relating to Nurse Educators' job satisfaction and perceived leadership styles and practices of Nursing Academic Leaders. The open coding according to participants and colleges for job satisfaction are as illustrated in Table II and leadership practices/ styles in Table III. 


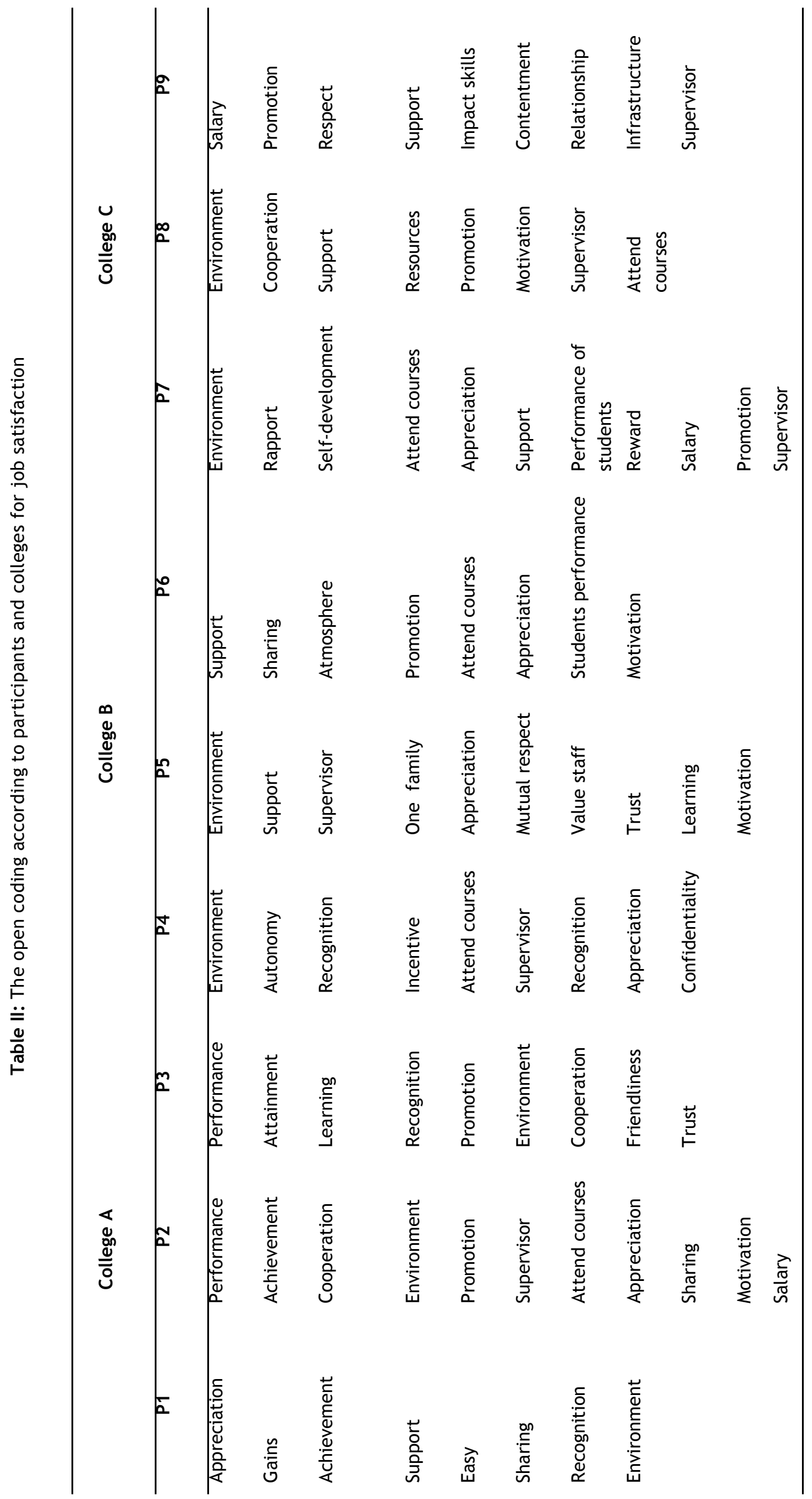




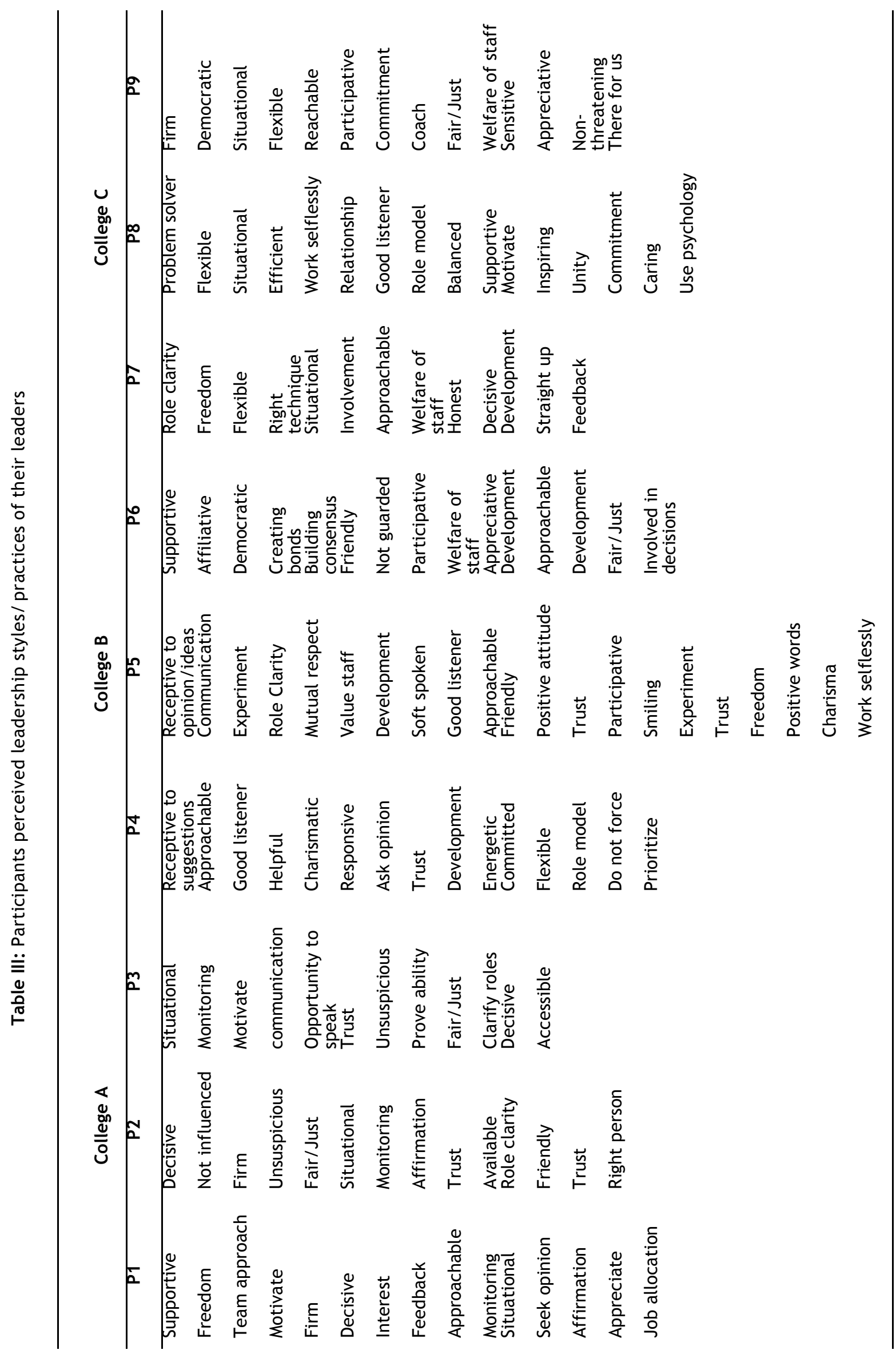

Axial coding for job satisfaction is as shown in Figure 1 and leadership practices/ styles in Figure 2. Only six themes were selected based on the highest number of times (frequency) mentioned by the nurse educators and are illustrated in the selective coding in colour boxes to synthesize the findings of nursing academic leadership styles/ practices with nurse educators job satisfaction (Figure 3) 


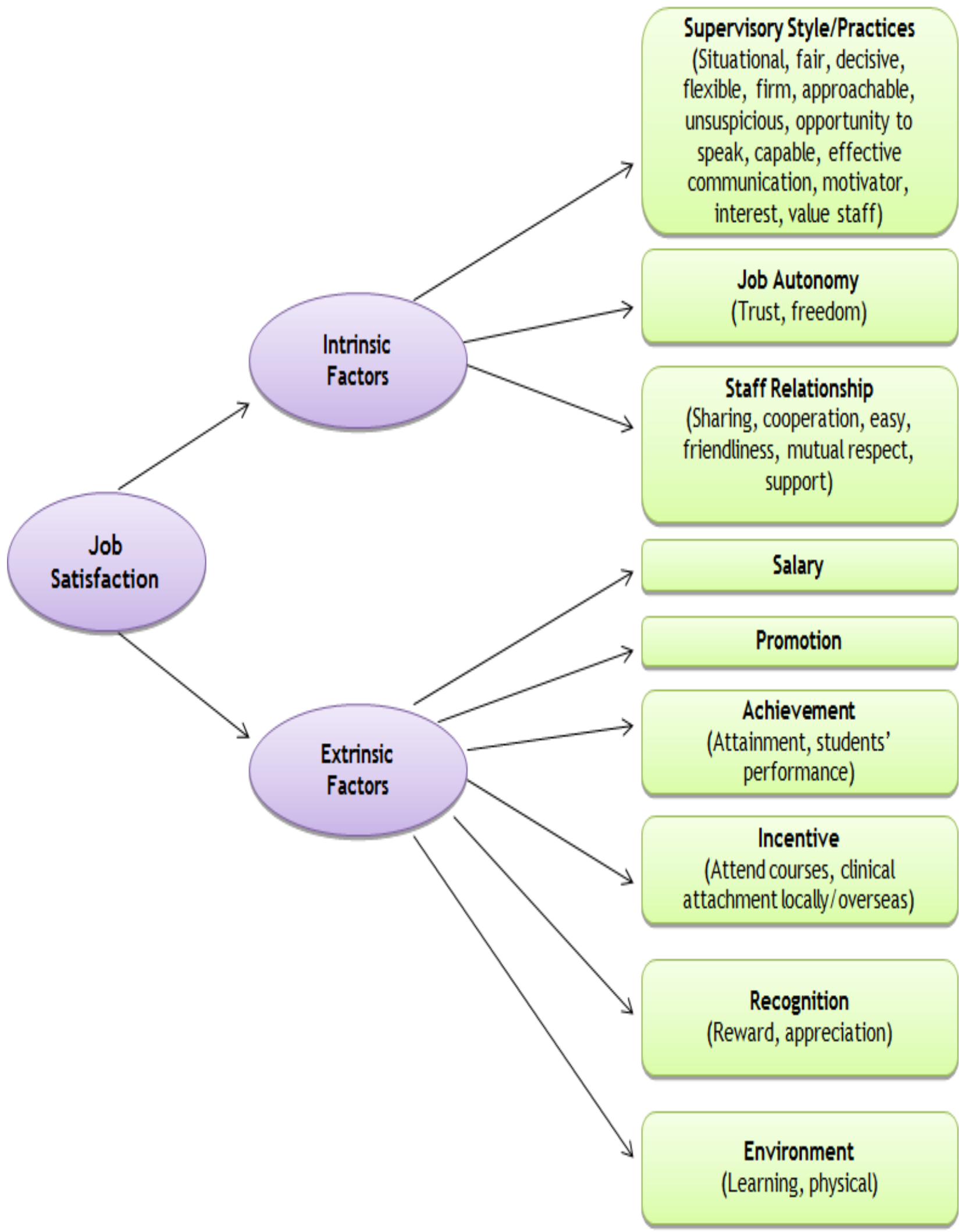

Figure 1: Axial Coding for Factors Leading to Job Satisfaction 


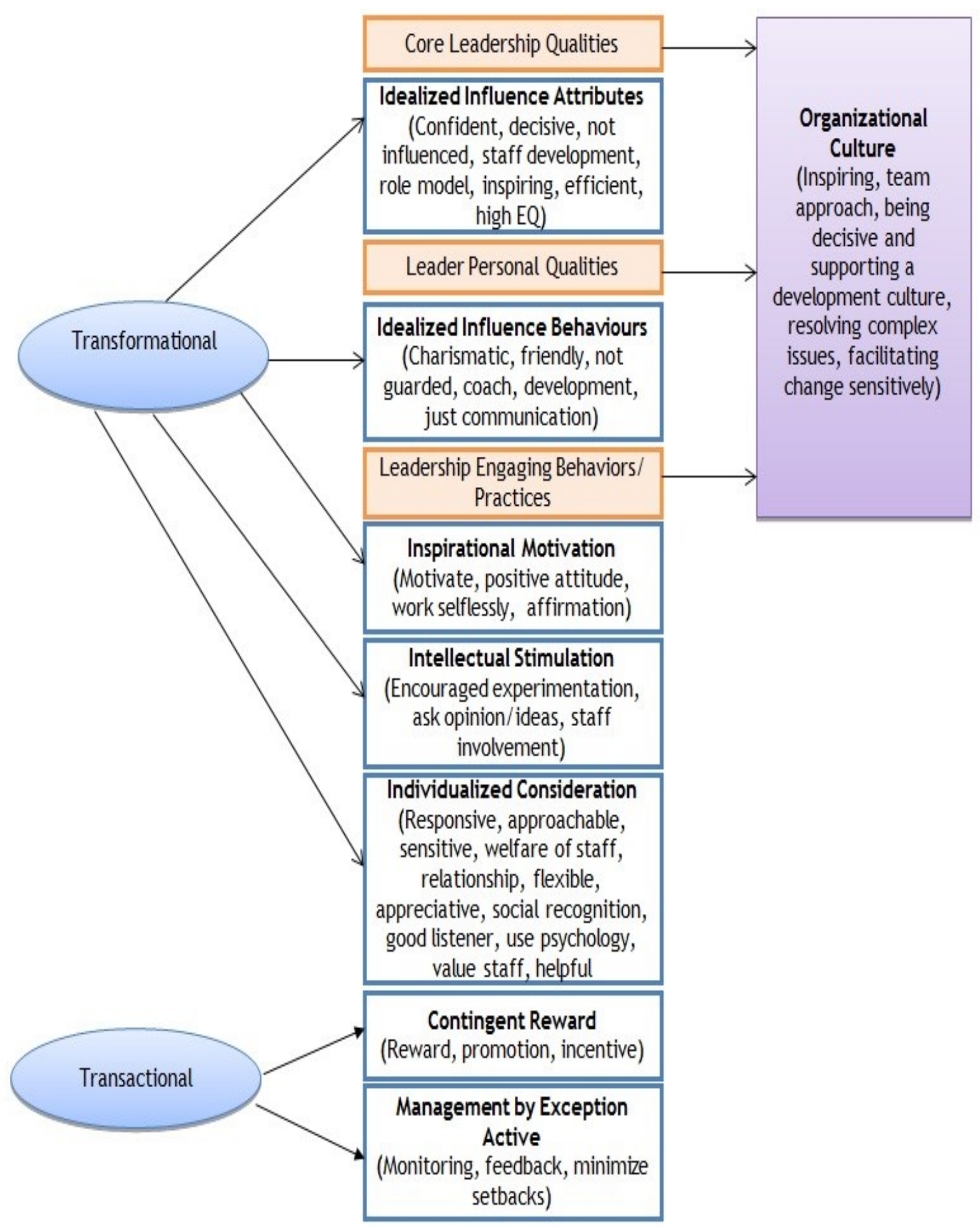

Figure 2: Axial Coding for Leadership Styles/Practices

The relationship between engaging behaviors of transformational and transactional leadership and wellbeing of subordinates in the enactment of a work place environment that is conducive in the nursing faculty is as shown in Table IV. 
Table IV: The Relationship of Leadership Constructs and Subordinates' Well- Being

\begin{tabular}{|c|c|c|c|}
\hline $\begin{array}{l}\text { Leadership } \\
\text { Construct }\end{array}$ & $\begin{array}{l}\text { Leader Core/Personal } \\
\text { Qualities/Engagement } \\
\text { Behaviour/Practices }\end{array}$ & $\begin{array}{l}\text { Organizational } \\
\text { Culture }\end{array}$ & Well Being \\
\hline $\begin{array}{l}\text { Tdealized Influence } \\
\text { Attributes }\end{array}$ & $\begin{array}{l}\text { Social charisma, confident, } \\
\text { inspiring, role model, } \\
\text { persuasive communication, } \\
\text { idealistic vision }\end{array}$ & $\begin{array}{l}\text { Tnspiring, Support a } \\
\text { development } \\
\text { culture }\end{array}$ & $\begin{array}{l}\text { Tntellectual } \\
\text { (Training/Learning) } \\
\text { Psycho-Social } \\
\text { (Opportunities for growth and } \\
\text { promotion, job design) } \\
\text { Emotional } \\
\text { (Empowerment) }\end{array}$ \\
\hline $\begin{array}{l}\text { Idealized Influence } \\
\text { Behaviour }\end{array}$ & $\begin{array}{l}\text { Professional treatment, } \\
\text { transparency, collegial } \\
\text { relationship, trust }\end{array}$ & $\begin{array}{l}\text { Team approach, } \\
\text { trust, job autonomy }\end{array}$ & $\begin{array}{l}\text { Psycho-Social } \\
\text { (Healthy and safe workplace, } \\
\text { teamwork, respect, supervisor and } \\
\text { group support) } \\
\text { Emotional } \\
\text { (Perception of fairness, } \\
\text { empowerment) }\end{array}$ \\
\hline $\begin{array}{l}\text { Inspirational } \\
\text { Motivation }\end{array}$ & $\begin{array}{l}\text { Motivate, positive attitudes, } \\
\text { work selflessly, affirmation, } \\
\text { persuasive communication }\end{array}$ & $\begin{array}{l}\text { Moving forward } \\
\text { building a shared } \\
\text { vision }\end{array}$ & $\begin{array}{l}\text { Psycho-Social } \\
\text { (Opportunities for growth and } \\
\text { development, collaboration) } \\
\text { Emotional } \\
\text { (Optimism, enthusiasm) }\end{array}$ \\
\hline $\begin{array}{l}\text { Intellectual } \\
\text { Stimulation }\end{array}$ & $\begin{array}{l}\text { Creativity, motivate to propose } \\
\text { ideas/opinion/solution, } \\
\text { participation decision making }\end{array}$ & $\begin{array}{l}\text { Moving forward and } \\
\text { resolving complex } \\
\text { issues }\end{array}$ & $\begin{array}{l}\text { Intellectual } \\
\text { (Learning) } \\
\text { Psycho-social } \\
\text { (Opportunities for growth and } \\
\text { development, respect) } \\
\text { Emotional } \\
\text { (Perception of being valued) }\end{array}$ \\
\hline $\begin{array}{l}\text { Individualized } \\
\text { Consideration }\end{array}$ & $\begin{array}{l}\text { Approachable, sensitive, good } \\
\text { listener, responsive, empathy, } \\
\text { support, coaching }\end{array}$ & $\begin{array}{l}\text { Build friendliness, } \\
\text { facilitating change } \\
\text { sensitively }\end{array}$ & $\begin{array}{l}\text { Emotiona } \\
\text { (Perception of being valued, respect) }\end{array}$ \\
\hline Contingent Reward & Reward, role clarity & $\begin{array}{l}\text { Motivational } \\
\text { incentive }\end{array}$ & $\begin{array}{l}\text { Physical Physiological } \\
\text { Payment }\end{array}$ \\
\hline $\begin{array}{l}\text { Management by } \\
\text { Exception (Active) }\end{array}$ & $\begin{array}{l}\text { Monitoring, minimize setbacks, } \\
\text { meet objectives }\end{array}$ & Compliance & - \\
\hline
\end{tabular}

\section{Recognition}

All nine participants (100\%) linked their job satisfaction to the recognition given to them by the students, director or the public in the form of appreciation, reward, promotion or the opportunity of upgrading oneself by attending courses or attachment. Importantly, the participants indicated that social recognition was highly valued. Amongst the comments were "a nice thank you note", "more respect", "recognizing their effort", a letter from the director or a personal thank you." The data revealed social rewards maybe more valued than tangible rewards as they are highly personalized and more meaningful. As one comment indicates "It's the recognition and appreciation that counts, not the gifts."

\section{Staff Relationship}

Seven out of nine participants (77.8\%) discussed the importance of the support given by the director and senior faculty members or relationship with their director, faculty members and staff members to their job satisfaction. Seven out of nine $(77.8 \%)$ participants of the study also revealed that their job satisfaction was mainly affected by their relationship with coworkers including the director. They discussed the sense of community that existed in their college and the sense of belonging like one big family. They expressed appreciation for directors who were firm and decisive but friendly and always smiling. "Our director is excellent as far as nurse educator support is concern. We are very family oriented." Nurse Educator \#5 emphasized that co-workers have played a big part towards their job satisfaction.

\section{Conducive Work Environment}

All nine participants $(100 \%)$ linked their job satisfaction to the conducive work environment at the college. Work environment is an extrinsic job satisfaction that has multiple dimensions but in this section only the sub factors obtained from the interview will be presented.

\section{Learning}

Nurse Educator \#2 said, "Being a nurse educator gives me the opportunity to learn and relearn as we have ample opportunity to be sent for courses either locally or overseas. This can have a positive impact on my desire to continue teaching." Nurse Educator \#8 further commented, "Teaching motivates me to continuously update my knowledge so that I can share with others indirectly 


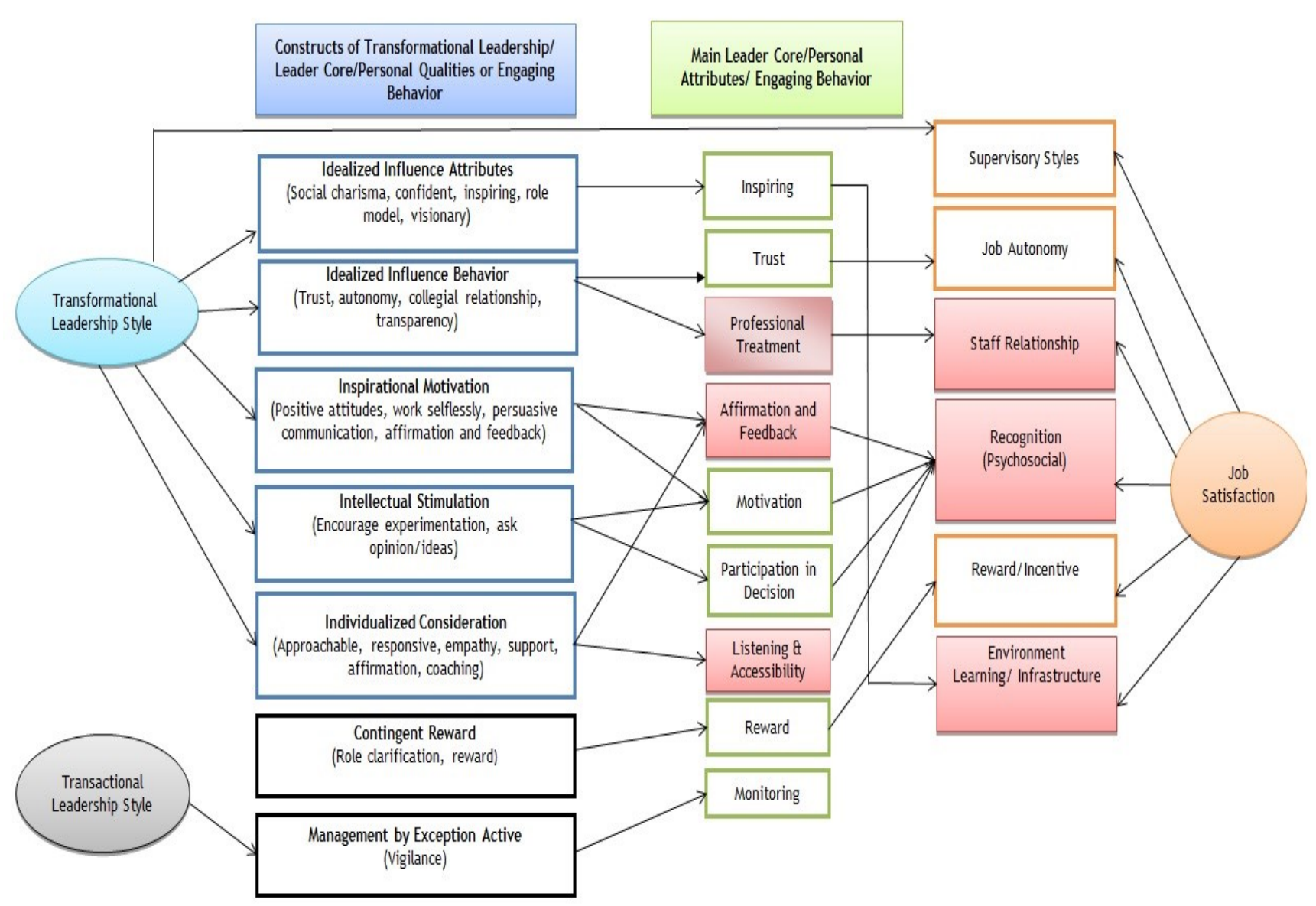

*Themes that were enacted from the qualitative study are those in filled colour boxes

Figure 3: Selective Coding for the Relationship of Leadership Styles/Attributes and Subordinates' Job Satisfaction

$\mathrm{RO}_{1}$ : To determine factors that Influenced Nurse Educators' job satisfaction.

contributing to the effectiveness of my teaching as well as providing the platform to develop myself." Nurse Educator \#7 further emphasized the importance of learning. She said, "I felt that I have been given the opportunity for self-development like being sent for courses and training."

\section{Physical Environment}

Participants in the interview identified the need for a safe environment that enabled a connection for the staff, was conducive to their well-being as well as the students, convenient and accessible, conducive for teaching and learning, considerate of impairments and provided safety and security. Nurse Educator \#9 lamented, "How could one work if the infrastructure is not planned properly? In the last couple of months, unwarranted accidents have occurred. Staff and students slipped and fall sustaining sprain and worse fracture."

\section{Supervisory Style}

Nurse educator \#1 said, “.... We are given the freedom to make decisions with the responsibilities given. I appreciate our director's team approach in soliciting her two assistant directors input on a lot of things." Nurse educator \#4 further reiterated, "The staff is given the autonomy to carry out their responsibilities. We felt we are trusted which have contributed to our job satisfaction." This is further confirmed by Nurse Educator \#5, "Our director always speaks positively and establishes clear expectations. She is always there for us, lending a hand whenever necessary. Nurse Educator \#9 added, "Our director supervisory style is very effective. I'm happy and satisfied working here."

$\mathrm{RO}_{2}$ : To determine how Nurse Educators perceived the leadership styles of their Nursing Academic Leaders.

The results of the qualitative component of this study confirms the positive influence of transactional leadership practices such as leaders communicating with their subordinates to explain how a task must be done and what rewards be given for a job done well. However, the majority of participants preferred transformational leadership that included them in the decision making and made them perceived as a valuable team member. They indicated that they responded more positively to directors who were able to share their vision with them in a positive manner and encouraged them to advance that vision. Most of the participants indicated their directors practiced situational leadership with a few stating democratic and 
afflictive leadership.

$\mathrm{RO}_{3}$ : To determine what specific leadership practices if any have encouraged nurse educators' job satisfaction?

\section{Professional Treatment}

Eight out of the nine participants $(88.9 \%)$ in this study indicated that they wanted to be treated as professionals who were valued for their expertise and trusted to make decisions in the best interest of the students and were also given the opportunity to be involved in the organization decision making. They also discussed the importance of professional development activities to help them improve, learn new instructional strategies and sharpen their skills. They preferred directors who are fair, firm and decisive and are able to address problems with individuals responsible to them. They indicated that they were motivated when they are_perceived as valuable team members. Nurse Educator \#1 praised her current director for seeking the opinion of her assistants. Nurse Educators \#5 commended her current director for trusting her to carry out the responsibilities given to her including the freedom to try new strategies. This is also agreed by Nurse Educator \#2 and \#3. They said, "Our director entrusts the staff to carry out the responsibilities given by according them freedom to execute the job. On her part, she actively monitors the progress and minimizes drawbacks." Nurse educator \#9 further added "I never like the idea of being threaten or being reprimanded in public. A leader should never do that. Reprimand with facts and never intrude into one's privacy if the situation does not warrant it."

\section{Feedback and Affirmation}

All nine participants $(100 \%)$ indicated that positive feedback and affirmation were important attributes that increased their job satisfaction. The three directors of the participating colleges were described as enthusiastic and positive by their nurse educators. The nurse educators of this study indicated they were motivated and inspired by the positive affirmations that they received from their directors. The director at College \#B was commended by her nurse educators who described her as having a positive attitude and leadership style. Nurse educator \#5 said, "She is always smiling. Whenever she sees you, she always has positive words for you. She has a way in making her nurse educators feel appreciated, by just little things like "walking the talk" and thanking you and recognizing your effort." The participants believed that college directors should encourage and reward them as they grow and improve in their practice. The responses from the participants indicated that they were inspired and affirmed by positive and encouraging leaders than by dictatorial leaders who demean them and their effort.

\section{Listening and Accessibility}

Seven out of nine participants $\mathbf{( 7 7 . 8 \% )}$ wanted directors that were approachable and know that their directors will listen to their thoughts, ideas and opinion even if they do not agree with them. Nurse Educator \#4 described her current director's leadership attributes as characterized by being receptive to suggestions, approachable, good listener and helpful. She identified her as being charismatic and responsive towards the problems of the staff. She also reiterated that her director will always ask opinion and ideas from her subordinates. Nurse Educator \#5 further explained that her director at College \#B had an open-door policy and was accessible not only to all the staff but also to students and parents.

\section{DISCUSSION AND CONCLUSIONS}

The significant relationship between nursing academic leadership styles and nurse educators' job satisfaction suggested that the academic nursing transformational leadership style play a prominent role on subordinates' job satisfaction and that nursing academic leaders practice transformational leadership and the attributes of transformational leadership has the ability to encourage subordinates to achieve more than just what they planned. ${ }^{17}$ Transformational leaders pay attention on the charismatic and affective elements of leadership which best met the expected leadership attributes by the subordinates. In the process of change, with their intellectual abilities and their sensitivity to the emotions of their subordinates, they were able to face the reality even though it was deemed as unpleasant. One possible reason for this significant relationship could possibly be explained from the aspect of transformational leadership attributes of idealized attributes and behaviours which resulted in the complete trust of the leader.

Another possible explanation could be from the inspiration motivation aspect of the transformational leader communicating a high standard of performance of his/her subordinates. Additionally, applying intellectual stimulation encourages subordinates to think creatively while individualized consideration enables subordinates' abilities to be developed to the highest potential. ${ }^{18}$ The Quran suggests the significance of practising consideration by the leader "By the mercy of God, you have been considerate with them, had you been rough and hard-hearted, they would have abandoned you" [3:159]. It is therefore likely that such relationship exists between transformational leadership style and subordinates' job satisfaction as this leadership style is able to develop followers' into leaders in a morally uplifting manner as leaders stimulate, challenge and motivate subordinates by emphasizing on the higher order development. ${ }^{18}$

Malaysian academic nursing leaders practice transformational leadership and that the attributes of transformational leadership had the ability to enhance subordinates' job satisfaction. It was believed that the subordinates' job satisfaction was acquired via the charismatic and affective elements 
of leadership that met the expected leadership attributes by the subordinates. Further, it was believed that transformational leadership attributes instilled confidence, trust and autonomy which in turn probably translated into better job satisfaction of subordinates as a result of low strain and high motivation. The Quran specifies that leaders should be role models for their followers. "The messenger of God is an inspiring model for those that put your hope in God and the Last Day and remember Him often" (Abdel-Haleem, 33:21).

The transactional leaders on the contrary focussed on the accomplishment of task and a good leaderworker relationship in exchange for desirable rewards. ${ }^{19}$ Transactional leadership practised by the nursing academic leaders were insignificant to subordinates job satisfaction. The possible explanation could be that the leaders' emphasis on payoffs for performance and corrective actions by the leaders were not as acceptable to that of the transformational leadership attributes practised by the nursing academic leaders. This possibly created a high demand-low resources condition resulting in high strain and low motivation.

Academic nursing leaders were believed to be a major contributing factor towards the working environment of subordinates which inadvertently affect job satisfaction as speculated by the Hagedorn $^{20}$ and the JD-R Theory. ${ }^{21}$ A positive working environment was described as encouraging trust worthy relationships as well as supporting the sentiment of treating people fairly. ${ }^{22}$ Being competent was characteristic of individuals holding management or leadership role which did not ensure effective leadership. The leader must possess the qualities of a transformational leader or had the potential of transformational leadership qualities to be effective. ${ }^{23}$ Additionally, effective leadership was enacted via "nearby transformational" or "engaging leadership" where the engaging leader enabled the development of an organization modelled by a culture of integrity, transparency, accessibility and genuine valuing of others. ${ }^{23}$ This indicated the engaging leader was concerned for the development and well-being of others as they were charismatic connectors who move actively, giving time democratically to others, engaged in brief but energetic conversations and were active listeners. ${ }^{24}$ The engaging leader's capability in articulating a shared vision and delegation evoked empowerment and development potential of subordinates. ${ }^{8}$ This coupled with active encouragement of subordinates to make decisions and solve problems fostered an environment where subordinates experienced high degrees of influence at work that led to psychological well-being corresponding to intrinsic states of happiness experienced by the individuals. ${ }^{25}$ The Quran suggests a few important characteristics that a leader should possess which include firmness, soft heartedness ${ }^{26}$ 3:159, integrity $^{26} 68: 4$, fairness ${ }^{27} 16: 90$, trustworthiness ${ }^{27}$ $17: 34$, building a community ${ }^{27} 3: 104$, wisdom ${ }^{27}$
27:35, respecting the individual [49:11], passion, consideration for people $e^{27} 3: 159$, performance and perseverance $^{27}$ 2:177 which were amongst the behaviours of ethical leadership as suggested by Dubrin. ${ }^{28}$ The vision enunciated by the prophet (pbuh) to his followers is based on the concept of justice "O believers! Stand firm for justice and bear true witness for the sake of God" [4:135] and tolerance." "We have made you a moderate nation" [2:143]; and mercy "We have not sent you except as a mercy to mankind." [21:107]. This message has been restated in the Quran to nurture the acceptance of group goals. The Quran and the practices of the Prophet (pbuh) envisaged the acceptable behavioural standards required of the followers. To achieve a desirable leadership, Islamic teachings provide the following guidelines on leadership;

First, as commanded in chapter 4, verse 59 of the Qur'an, and elsewhere in the Qur'an, loyalty to ulul -amr, i.e., those in charge (leaders), is stated subsequently to the obedience of Allah (s. w. t.) and his Messenger (s. a. w.), which shows the importance that Islam invests in the leadership office. This does not, however, reflect theocracy; on the one hand, Islam teaches the importance of rule of law, in which the leader is not more than a servant, hired for the duty of public service, yet as reflected in this verse, loyalty to leadership basically means to respect the chain of command in given administrations. Leaders are required to play effective leadership roles, so that organizational aim of given administrations are achieved. Loyalty is then due to leaders as long as they, leaders are committed to achieve justice and to rule of law.

Second, as stated in chapter 49 , verse 13 , one of the basic elements of the Islamic moral teachings is the concept of equality, whereby in the eyes of Almighty, man and woman are inherently equal; no one is higher than others by virtue of colour, ethnic or race. This requires leaders to treat their subordinates in the workplace equally in terms of sharing given resources, job distribution, salary allocation, remuneration and promotions.

Third, another important area of leadership characteristics is the decision-making style. As mentioned in chapter 3 , verse 159 , and elsewhere in the Qur'an, leaders are required to offer teamoriented decision-making style, whereby leaders seek the opinion and the participation of subordinates and workmate in the process of making decisions on given administrative matters. In this verse, the Qur'an commands "consult them in affairs of the moment", which implies participative and transactional leadership in which the leader mobilizes available human resources in given institutions to achieve desirable goals of the organization.

Fourth, integrity and trust are among basic Islamic teachings on leadership, whereby the best person to hire for given jobs (inna khayra man ista'jarta) is 
the person who has integrity and trust (al-qawi alamin). In chapter 28 , verses 26 , the Qur'an states "truly the best of men for thee to employ is the (man) who is strong and trusty"; hence leadership should be illustrated with due strength and honesty.

Fifth, Islamic leadership characteristics include the attributes of being skilful (alim) and competent (makin). Leaders are expected to have the necessary ability, knowledge, and relevant skills to do given tasks successfully. These traits could be earned by means of experience and training, or perhaps these traits could be inborn attitudes, in both cases, Islamic ethics requires given leadership duties to be assigned to those who have necessary skills and competence.

As such there are many similarities in the conventional and Islamic leadership approaches in the enactment of engaging leadership (nearby transformational leadership) where the leaders are seen as approachable and treat subordinates with humility, interest, respect and accessibility. Given this reality through the lens of Islam, leaders are expected to be humble (mutawadi'), trustworthy (amin), skilful ('alim) and competent (makin) with due strength (quwah) and commitment to work (mudawamatul al-amal).

In conclusion, this study had found a strong and positive relationship between academic nursing transformational leadership style and nurse educators' job satisfaction indicating that transformational leadership played a highly significant role to that of nurse educators' job satisfaction. Transactional leadership on the other hand being a relationship compliance subordinateleadership style served as the basis of human resource management indicated weak relationship with subordinates' job satisfaction. The findings of this study have contributed to the pool of knowledge especially pertaining to the effective leadership practices/ behaviours required to bring about subordinates' job satisfaction which can enhanced their commitment towards the organization and ultimately better organizational outcomes. Social recognition of subordinates was found to be perceived as a lacking leadership practice amongst academic nursing leaders. As such it is hope that the findings of this study can be used for self-improvement and development by the leaders themselves via self-reflection. Additionally, this study has helped pave the way for all parties concerned to understand the importance of setting up a leadership development and training program to improve the leadership qualities of academic nursing leaders. The information also enhanced the understanding that the relationship of engaging leadership (nearby transformational leadership), well-being and job satisfaction are related to a working environment where subordinates perceive their work as meaningful, are involved in their job and experience high degrees of influence.
I am indebted to the Training Division, Ministry of Health Malaysia for granting me the permission to conduct the study. To all my ex-colleagues in the colleges under the Ministry of Health Malaysia as well as in the Training Division, Ministry of Health Malaysia, thank you for the cooperation and assistance extended to me especially during data collection.

\section{REFERENCES}

1. Faila KR, Stichler JF. Manager and staff perceptions of the manager's leadership style.Journal of Nursing Administration 2008; 38(11): 480-487.

2. Loke-Foong JC. Leadership behaviors: effects on job satisfaction, productivity and organizational commitment. Journal of Nursing Management 2001; 9: 191-204.

3. Grossman S, Valiga T. The new leadership challenge: Creating the future of nursing. Philadelphia: F. A. Davis Company, 2000.

4. Ulrich B, Buerhaus P, Donelan K, Norman L, Dittus R. Magnet status and registered nurse view of the work environment and nursing as a career. Journal of Nursing Administration 2009; 39(7/8):54-62.

5. Bangajam N. Job satisfaction among nurse educators in nursing colleges, Ministry of Health Malaysia. Masters Dissertation. University of Malaya, Kuala Lumpur, 2009.

6. Barnett $T$, Namasivayam P, Narudin DAA. A critical review of the nursing shortage in Malaysia. Journal compilation 2010. International Council of Nurses

7. Kousez JM, Posner BZ. Academic administrator's guide to exemplary leadership. San Francisco: Jossey-Bass, 2005

8. Madlock PE. The link between leadership style, communicator competence and employee satisfaction. The Journal of Business Communication 2008; 45(1): 61-78

9. Div T, Shamir B. Followers' developmental characteristics as predicting transformational leadership: A longitudinal study. Leadership Quarterly 2003; 14(3): 327-344.

10. Bass BM. Transformational leadership. Mahwah: Lawrence Erlbaum associates, 1997

11. Bass BM, Avolio BJ. Improving organizational effectiveness through transformational leadership. Thousand Oaks: Sage, 1994.

12. De Geest $\mathrm{S}$, Claessens $\mathrm{P}$, Longerich $\mathrm{H}$ and Schubert M. Transformational leadership: worthwhile the investment! European Journal of Cardiovascular Nursing 2003; 2: 3-5.

13. Bass BM, Avolio BJ. The implications of transactional and transformational leadership for individual, team and organizational development. Research in Organizational 
Change and Development 1990; 4(1): 231-272

14. Glatthorn A, Joyner R. Writing the winning thesis or dissertation: A step by step guide. 2nd ed. Thousand Oaks, CA: Corwin Press, 2005

15. Ary D, Jacobs LC, Razavieh A, Sorenson C. Introduction to research in education. 7th ed. Belmont: Thomson Wadsworth, 2006.

16. Guba EG, Lincoln, YS. Competing paradigms in qualitativeresearch. In Denzin NK\& Lincoln YS, eds. The handbook of qualitative research. Thousand Oaks: Sage, 1994.

17. Krishnan VR. Transformational leadership and outcomes: Role of relationship duration. Leadership and Organization Journal 2005; 26(5-6): 442-457.

18. Bass BM, Avolio BJ. Training full range leadership: A resource guide for training with the MLQ. Redwood City: Mind Garden, 1999.

19. Muenjohn A, Armstrong A. Evaluating the structural validity of the Multifactor Leadership Questionnaire (MLQ), capturing the leadership factors of transformational-transactional leadership. Contemporary Management Research 2008; 4(1):3-14.

20. Hagedon LS. Conceptualizing faculty job satisfaction: Components, theories and outcomes. New Directions for Institutional Research. San Francisco: Jossey Bass, 2000.

21. Bakker AB, Demerouti E, Euwema MC. Job resources buffer the impact of job demands on burnout. Journal of Occupational Health Psychology 2005; 10: 170-180.

22. Blake N, Blayney F, Loera T, Rowlett C, Schmidt, D. A model of authentic leadership to support a healthy work environment. $A A C N$ Advanced Critical Care 2012; 23(4): 358-361.

23. Metcalfe BA, Metcalfe JA. Engaging leadership: Creating organizations that maximize the potential of their people. Research Insight 2009, CIPD.

24. Hewitt $A$. The engaging leader: Experiences, beliefs and behaviours; 2014. Available at www.aonhewitt.com. Assessed January 12, 2015

25. Diener E, Oishi S, Lucas RE. Personality, culture and subjective well-being: Emotional and cognitive evaluations of life. Annual Review of Psychology 2003; 54(1): 403-425.

26. Malik MF. Translation of the meanings of AlQuran. Houston, TX: The Institute of Islamic Knowledge, 1997.

27. Abdel-Haleem. The Qur'an, A new translation. London: Oxford, 2004

28. Dubrin AJ. Leadership: Research findings, practice and skills, Boston, MA: Houghton Mifflin, 2007. i. The Prophet (s. a. w.) said: "Every-one of you is a protector and every-one is guardian of his or her responsibility. A ruler or administrator is also ra'i, .i.e., accountable or steward for those who are under his or her charge, a man is a steward in respect of his family members of his house, a woman is a steward in respect of her house and children. In short every one of you is steward and is accountable for those who are placed under his care." (Reported by Bukhari and Muslim)

ii. In his book Kitab al-Kharaj (book of taxation), he highlighted the basic framework of leadership and state policies and its political limitations.

iii. In his two correlated books, al-Adab al-Kabir and al-Adab as-Saghir, Ibn al-Muqafa dealt with the various aspects of state, ruler's attitude, the administrator's behaviour, obligation and his bureaucratises through religious sentiment.

iv. Abu al-Hassan Ali Ibn Muhamad b. Habib alMawardi, made a considerable contributions on the Islamic administration, tafsir, ethics and many other fields. Among many of his works are: al-Ahkam al-Sultaniya wal Wilayah al-Diniyya, i.e., the Ordinances of

Government. Qanun al-Wasarah, i.e., Laws regarding the Ministers, and Kitab Nasihat alMuluk, i.e., The Book of Sincere Advice to Rulers.

v. In his two correlated books, al-Adab al-Kabir and al-Adab as-Saghir, Ibn al-Muqafa dealt with the various aspects of state, ruler's attitude, the administrator's behaviour, obligation and his bureaucratises through religious sentiment, see Ibn Muqafa', al-Adab al-Kabir and wal-Adab as-Saghir, (Beirut: Dar al-Kitab al-Arabi, 1994).

vi. Abu Hamid Mohd Al-Ghazali, Kitab Mizan alAmal, (Cairo: Maktabat Kurdistan al-Ilmiyyah, 1908).

vii. Abu al-Hasan Ali B. Mohd al-Mawardi, 'Ali ibn Muhammad, al-Ahkam as- Sulthaniyyah wa alWilayat al-Diniyah. (Bayrut : Dar al-Kutub al'Ilmiyah, 2006)

viii. Abu al-Hassan Ali Ibn Muhamad b. Habib alMawardi, made a considerable contributions on the Islamic administration, tafsir, ethics and many other fields. Among many of his works are: al-Ahkam al-Sultaniya wal Wilayah al-Diniyya, i.e., the Ordinances of Government. Qanun al-Wasarah, i.e., Laws regarding the Ministers, and Kitab Nasihat alMuluk, i.e., The Book of Sincere Advice to Rulers.

ix. See for example the works of al-Mawardi, AlAhkam al-Sultania wal Wilayat al-Diniyah,.

x. See: Shaukat Ali, Administrative Ethics in a Muslim State, (Lahore: Publishers United, 1975).

xi. See: Al-Qardhawi, Yusuf, Dawr al-Qiyam wa al -Akhlaq fi al-Iqtisad al-Islami, (Cairo:

Maktabat Wahbah, 1995). 
xii. The Qur'an states (4:59): “O ye who believe! Obey Allah, and obey the Messenger, and those charged with authority among you. If ye differ in anything among yourselves, refer it to Allah and His Messenger, if ye do believe in Allah and the Last Day: That is best, and most suitable for final determination." (al-Niasa', 59)

xiii. The Qur'an (49: 13): “O mankind! We created you from a single (pair) of a male and a female, and made you into nations and tribes, that ye may know each other (not that ye may despise (each other). Verily the most honoured of you in the sight of Allah is (he who is) the most righteous of you. And Allah has full knowledge and is well acquainted (with all things).

xiv. The Qur'an (3:159):

xv. The Qur'an states (28: 22-25): “And when he arrived at the watering (place) in Madyan, he found there a group of men watering (their flocks), and besides them he found two women who were keeping back (their flocks). He said: "What is the matter with you?" They said: "We cannot water (our flocks) until the shepherds take back (their flocks): And our father is a very old man. So he watered (their flocks) for them; then he turned back to the shade, and said:"O my Lord! truly am I in (desperate) need of any good that Thou dost send me! Afterwards one of the (damsels) came. (back) to him, walking bashfully. She said: "My father invites thee that he may reward thee for having watered (our flocks) for us." So when he came to him and narrated the story, he said: "Fear thou not: (well) hast thou escaped from unjust people. Said one of the (damsels): "O my (dear) father! engage him on wages: truly the best of men for thee to employ is the (man) who is strong and trusty. He said: I intend to wed one of these my daughters to thee, on condition that thou serve me for eight years; but if thou complete ten years, it will be (grace) from thee. But I intend not to place thee under a difficulty: thou wilt find me, indeed, if Allah wills, one of the righteous. He said: Be that (the agreement) between me and thee: whichever of the two terms I fulfill, let there be no illwill to me. Be Allah a witness to what we say."

xvi. Professionalism is defined as the professional status, methods, character and standards. The expertness characteristic of a professional person, or skilful, by virtue of possessing special knowledge (The EnglishArabic Dictionary of Professional Business Terms, by Saba and Co. (London: Middle East Economic Digest: 1987), p.104. 